\title{
BIOEDUSCIENCE
}

ISSN: 2614-1558

\section{Potential of Bioactive Compounds of Arenga Vinegar as Traditional Medicine Through Reverse Docking Technique}

\author{
Reza Fauzi Dwisandi1, Diana Hernawati ${ }^{*}$, Egi Nuryadin ${ }^{1}$ \\ 1Program Studi Pendidikan Biologi FKIP, Universitas Siliwangi, Jl. Siliwangi No. 24 Kota Tasikmalaya Jawa Barat 46115
}

*Correspondent Email: hernawatibiologi@unsil.ac.id

\section{ARTICLE INFO}

\section{Article history}

Received: 14 Apr 2021

Accepted: 11 Jul 2021

Published: 31 Aug 2021

\section{Keywords:}

Arenga Vinegar;

Bioactive Compound;

Reverse Docking;

\section{A B S T R A C T}

Background: Arenga vinegar (Arenga pinnata) has been trusted by the indigenous people of Kampung Kuta as traditional medicine, one of which is used as a diabetes medicine. For this reason, this study aims to examine the bioactive compounds contained in Arenga vinegar, namely acetic acid, which is predicted to be scientifically proven using reverse docking techniques. Methods: This research is descriptive qualitative research, by interpreting the data obtained from Pubchem and PDB database \& Discovery Studio, AutoDock Tools, AutoDock Vina, and USCF Chimera software. Results: There is a binding pose between acetic acid and the sucrase-isomaltase enzyme (3LPO), the lowest binding affinity value is $-3.2 \mathrm{kcal} / \mathrm{mol}$, and the binding site occurs hydrophobic interactions with the amino acids Trp327(A), Asp355(A), Ile392(A), Trp470(A), Phe604(A), His629(A), Trp586(A) as well as hydrogen bonding to the amino acid asp472(A). Conclusions: The acetic acid-binding pose binds well to the sucrase-isomaltase enzyme so that the binding affinity value appears even though the value is not too low and the binding site occurs. This can be used as proof of the indigenous people's belief of Kampung Kuta, namely the treatment of Arenga vinegar as a diabetes drug, especially as a level control blood sugar.

\section{Potensi Senyawa Bioaktif Cuka Aren Sebagai Obat Tradisional Melalui Teknik Reverse} Docking

\section{A B S T R A K}

\section{Kata kunci:}

Arenga Vinegar;

Bioactive Compound;

Reverse Docking;
Background: Cuka aren (Arenga pinnata) selama ini dipercaya oleh masyarakat adat Kampung Kuta sebagai pengobatan tradisional, salah satunya digunakan sebagai obat diabetes. Untuk itu tujuan dari penelitian ini menguji senyawa bioaktif yang terdapat pada cuka aren yaitu asam asetat yang diprediksi sebagai pembuktian secara ilmiah dengan menggunakan teknik reverse docking. Metode: Penelitian ini merupakan penelitian kualitatif deskriptif, dengan menginterpretasikan data yang diperoleh dari database dan software. Hasil: Terjadi pose pengikatan antara asam asetat dengan enzim sucrase-isomaltase, nilai afinitas pengikatan paling rendah yakni sebesar -3,2 $\mathrm{kcal} / \mathrm{mol}$, dan site pengikatan terjadi interaksi hidrofobik pada asam amino Trp327(A), Asp355(A), Ile392(A), Trp470(A), Phe604(A), His629(A), Trp586(A) serta terjadi ikatan hidrogen pada asam amino Asp472(A). Kesimpulan: Pose pengikatan asam asetat mengikat dengan baik terhadap enzim sucrase-isomaltase, sehingga muncul nilai afinitas pengikatannya meskipun nilainya tidak terlalu rendah dan terjadi site pengikatan. Hal tersebut dapat dijadikan sebagai pembuktian kepercayaan masyarakat adat Kampung Kuta yakni pengobatan cuka aren sebagai obat diabetes khususnya sebagai pengontrol kadar gula darah.

(C) 2021 by authors. License BIOEDUSCIENCE. UHAMKA, Jakarta. This article is open access distributed under the terms and conditions of a Creative Commons Attribution (CC-BY) license.

\section{Introduction}

Arecaceae family plants are widely used by the people of Kampung Adat Kuta, Tambak Sari Subdistrict, Karangpaninggal Village, Ciamis Regency as traditional medicine. The people of Kampung Adat Kuta use palm vinegar fermented nira water (Arenga pinnata) to treat fever, aches, liver, diabetes, stomach acid and external wounds. Scientific proof is needed by testing the bioactive compounds contained in the palm vinegar. 
Current technological advances led to the initial procedure of testing bioactive compounds contained in palm vinegar, and it is necessary to predict in advance to see the compound's performance by modelling chemical structures through an in silico approach. (Hairunnisa, 2019). This aims that wet experiment testing (pre-clinical) in the next stage, namely with in vitro and in vivo approaches in practice, will be more targeted and avoid trial and error. It will shorten the clinical testing time in the next stage. The technique used in this in silico approach is reverse docking which is a technique to analyse the potential of a compound against the target protein in the human body. (Zheng et al., 2011).

The docking program will predict the binding between small molecules and target complex proteins to find the best binding by ranking by specific assessments. (Park \& Cho, 2017). This assessment can be reviewed from the binding pose, binding site, and binding affinity (Pangastuti et al., 2016). Most drug receptors are proteins. Receptors are a special class of proteins that bind to specific ligand molecules; when ligands bind to their receptors, they can change conformation, transmitting signals into the cell. (Casem, 2016).

Related to this, researchers conducted a library study on the content of bioactive compounds in palm vinegar (Arenga pinatta). However, unfortunately, there have been no studies that identify the content of palm vinegar, but there is research on determining the quality of palm vinegar that some mineral contaminants can be considered as bioactive compounds such as $\mathrm{Cu}$ and $\mathrm{Zn}$, and in palm vinegar there are compounds $\mathrm{NaCl}$, glucose, fructose and its main component is acetic acid resulting from the fermentation stage of simple sugars into alcohol, furthermore, alcohol is fermented into high-grade acetic acid, with a concentration value of $7.20 \%$. (Baharuddin et al., 2009). As a comparison that, acetic acid is also the main compound of apple cider vinegar with a concentration of 39\%. (Beheshti et al., 2012). Acetic acid, better known as vinegar acid $(\mathrm{CH} 3 \mathrm{COOH})$, is a liquid-shaped compound, colourless, pungent-smelling, has a sharp sour taste, and dissolves in water, alcohol, glycerol, etc ether. (Hardoyo et al., 2017).

Therefore, researchers tried to predict acetic acid compounds to visualise their binding to receptor proteins associated with diseases believed by the indigenous kuta community, through reverse docking techniques, by reviewing binding poses, binding affinities and binding sites. Acetic acid, can inhibit the activity of disaccharide enzymes namely sucrase, maltase, trehalase and lactase (Toonen et al., 2012). Based on the results of searches in PDB with the keyword enzyme, a protein derived from the enzyme disaccharide sucrase-isomaltase was obtained with GDP ID 3LPO.

\section{Methods}

Descriptive qualitative research was conducted to prove the bioactive compounds of palm vinegar, acetic acid. The study results will be associated with the belief of Kampung Adat Kuta that palm vinegar can be used to control blood sugar levels by interpreting data obtained from databases and software.

The reverse docking stage is by predicting the target protein. Molecular docking, downloading and preparing ligands in acetic acid using the PubChem database, Discovery Studio software, and AutoDock Tools. Download and preparation of sucrase-isomaltase receptor proteins using GDP databases, Discovery Studio software and AutoDock Tools.

Molecular tethering uses AutoDock Tools software, AutoDock Vina, and visualises interactions between acetic acid compounds with sucrase-isomaltase target proteins using USCF Chimera software and Discovery studio. Using the Miles and Huberman model, data analysis techniques include data reduction, data presentation, and conclusion withdrawal and verification. (Sugiyono, 2016).

\section{Results}

This study determined target proteins with a literature study of previous experimental studies on diseases related to fever, aches, liver, diabetes, stomach acid, and external wounds. Acetic acid compounds cannot be predicted in webserver http://www.pharmaexpert.ru/passonline/ because they have only two carbon atoms. The literature study results obtained acetic acid compounds that can be tethered to disaccharide enzymes in the human small intestine, controlling blood levels for people with diabetes.

\section{Download and Preparation of Acetic Acid Ligand}

Downloading ligand files in the form of acetic acid can be done on the PubChem website and can be accessed on the https://pubchem.ncbi.nlm.nih.gov/ page. The search process is done by writing the name acetic acid, then downloaded in 3D conformer with Sybil Data Files format (*.sdf) and then stored in a particular folder for molecular docking purposes. After that, ligand is predicted using Discovery Studio software and AutoDock Tools.

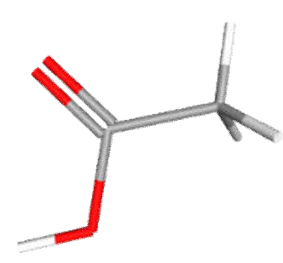

(a)

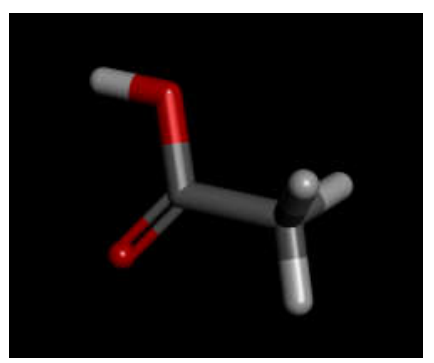

(b) 


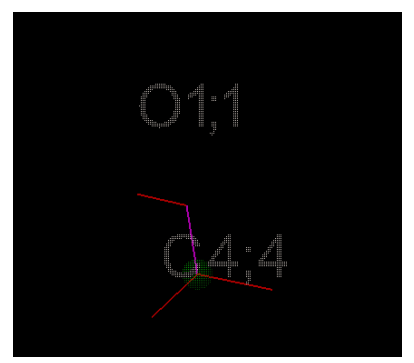

(c)

Figure 1. (a) 3D structure of natural compounds acetic acid (PubChem, 2021) (b) Ligand acetic acid preparation using discovery studio software (C) Ligand acetic acid preparation using AutoDock Tools software

\section{Download and Preparation of Sucrace-Isomaltase Receptor Proteins}

Downloading of receptor protein files or target macromolecules can be done at the Protein Data Bank site which is a repository of biological structures, and can be accessed on the https://www.rcsb.org/ page by looking for receptor files in the form of disaccharide enzyme derivatives, while the search results found are sucraseisomaltase with codes named 3LPP and 3LPO.

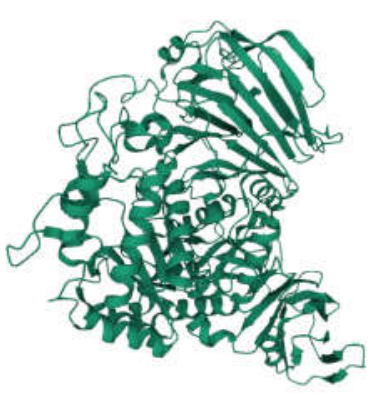

(a)

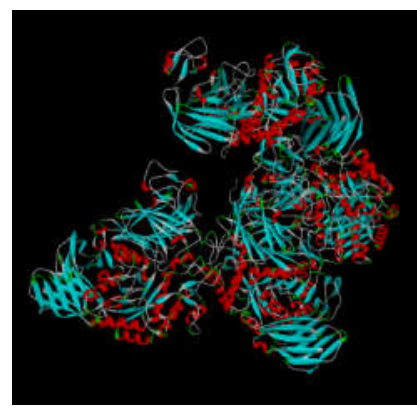

(b)

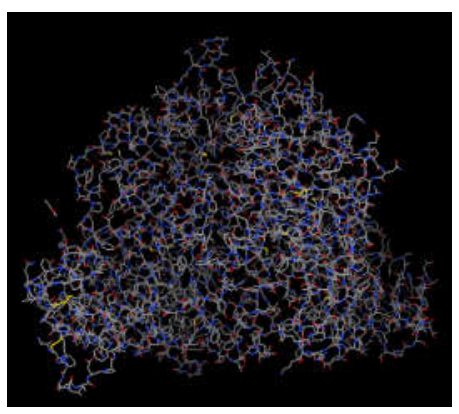

(c)

Figure 2. (a) Sucrase-isomaltase receptor protein (3LPO) (PDB, 2021) (b) 3LPO receptor protein prepared using Discovery studio software (C) Protein receptor $3 \mathrm{LPO}$ resulting from separation of preparation chain using AutoDock Tools software

The protein used in the study was a sucrase-isomaltase receptor protein (3LPO) that has a chain of 4, A B C D, and there is only one congenital ligand in the form 2 -acetamido2-deoxy-beta-D-glucopyranose and no other residues.
Therefore, protein (3LPO) is cleaner in structure than protein (3LPP), facilitating researchers in preparation. After that, the receptor protein (3LPO) is interpreted using Discovery Studio software and AutoDock Tools.

\section{Molecular Tethering}

Before molecular tethering, the grid box is done using AutoDock Tools software. Gridbox creation data is used to call AutoDock Vina applications using Command Prompt so that the tethering process can occur. The results of creating a grid box are written on a notepad file, as in Figure 3.

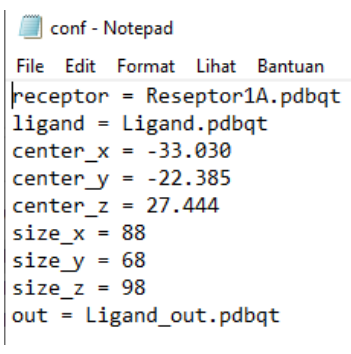

(a)

\begin{tabular}{crrr} 
mode $\mid \begin{array}{r}\text { affinity } \mid \\
\text { (kcal/mol) } \mid\end{array}$ rmsd $1 . b . \mid$ rmsd u.b. \\
\hline 1 & -3.2 & 0.000 & 0.000 \\
2 & -3.1 & 15.082 & 15.344 \\
3 & -3.1 & 1.773 & 1.901 \\
4 & -3.1 & 34.921 & 35.400 \\
5 & -3.0 & 1.858 & 2.620 \\
6 & -2.9 & 14.021 & 14.412 \\
7 & -2.9 & 38.831 & 39.150 \\
8 & -2.9 & 25.519 & 25.925 \\
9 & -2.9 & 39.129 & 39.336 \\
Writing output ... &
\end{tabular}

(b)

Figure 3. (a) Notepad file resulting from the creation of grid box (b) molecular tethering results in the form of affinity binding values

Visualisation of Interactions Between Acetic Acid Compounds And Target Proteins Sucrase-Isomaltase (3LPO) Chain A

After tethering using Autodock Vina, file Ligand_out.pdbqt image 3(a) will appear, can be opened in the Discovery studio software. Ligands with the lowest binding affinity of $-3.2 \mathrm{kcal} / \mathrm{mol}$ are copied and stored in the receptor folder. The result stored as a receptor visualises it in 3D and 2D using UCSF Chimera and Discovery Studio software (figure 4).

The results of 2D visualisation using discovery studio software that the results of molecular docking visualisation occurred hydrophobic interactions in amino acids Trp327(A), Asp355(A), Ile392(A), Trp470(A), Phe604(A), His629(A), Trp586(A) and hydrogen bonding in amino acids Asp472(A). 


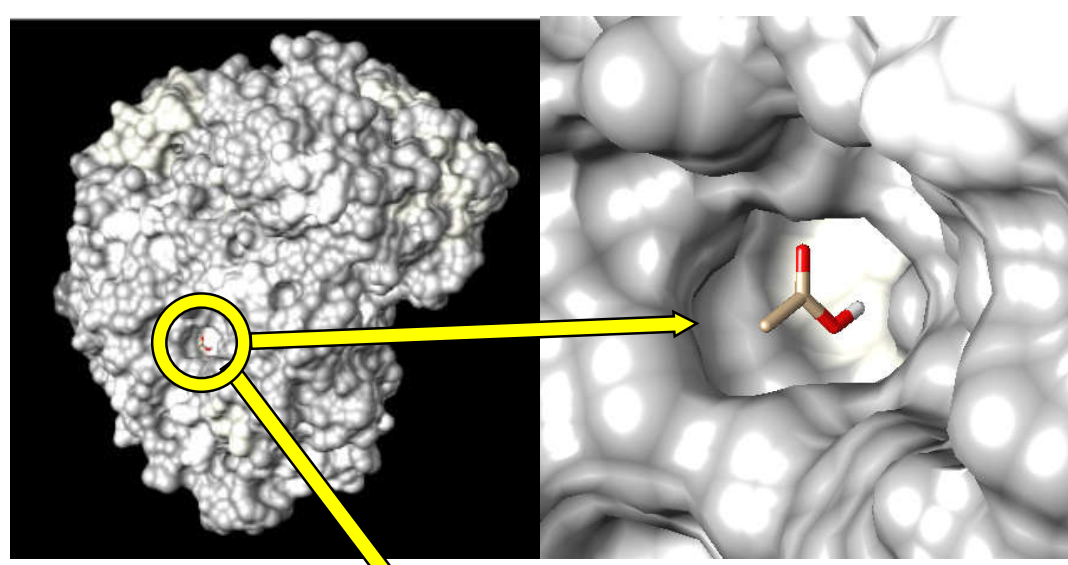

(a)
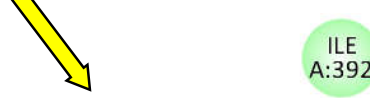

A:392

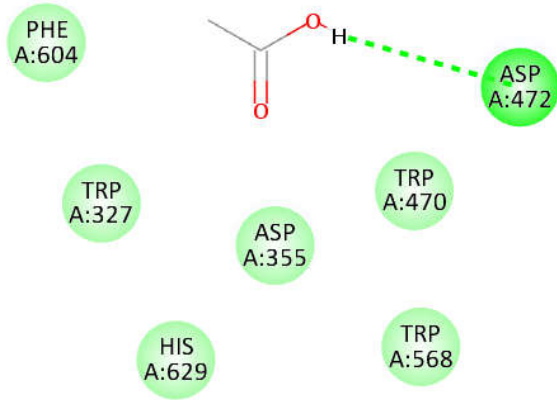

(c)

Figure 4. (a) Site binding interaction between acetic acid and chain sucrase-isomaltase enzyme A using UCSF Chimera Software software (b) 2D visualisation of acetic acid with chain sucrase-isomaltase enzyme using Discovery Studio software

\section{Discussion}

Reverse docking focuses on the ability of one or more compounds to bind to multiple evaluated proteins in silico, which is done by molecular docking techniques, which are helpful computational methods for identifying potential interactions between molecules and their pharmacological targets. It is helpful to identify molecular targets of bioactive compounds to be predicted, so it will propose new molecular mechanisms, find alternative indications of drugs, or predict drug toxicity. (Domling, \& VelascoVelazquez, 2020). In short reverse docking is a technique that becomes a tool in repositioning or finding drugs by analysing the potential of a compound against target proteins in the human body. (Kharkar et al., 2014; Zheng et al., 2011).

The ligand used in this study is acetic acid which is the main bioactive compound in palm vinegar. Acetic acid or vinegar acid is a saturated fatty acid compound that does not contain a double bond with carbon atoms as much as two pieces with the molecular formula $(\mathrm{CH} 3 \mathrm{COOH})$. Acetic acid is the main product in the fermentation of carbohydrates by the breeding organism, the form of liquid, colourless, pungent smell, has a sharp sour taste and dissolves in water, alcohol, glycerol, and ether (Hardoyo et al., 2017; Murray et al., 2017). Ligands are molecules that bind to the site of a specific complex target protein molecule. (Kemp, 2013).

The target protein or receptor protein is a particular class of proteins that bind to specific ligand molecules. When the ligand binds to the receptor, the receptor can change conformation, transmitting signals into the cell (Casem, 2016). One type of receptor protein molecule is an enzyme that is a nonliving thing produced by living cells and makes up most of the total protein in the cell, its function as a biocatalyst which is an essential component in metabolism and biological processes (Ferdinal, 2005; Susanti \& Febriana, 2017).

Disaccharide enzymes (glycosidase enzymes) as receptor proteins were used in this study. This enzyme is located in the mucous cells of the intestine, precisely in the small intestine. (Murray et al., 2017; Wahyuni, 2017). Glycosidase activity is found in four different types of glycoproteins: glucoamylase, complex sucrases, trehalases and lactases-glucosylsamidase (Wahyuni, 2017). Sucrase and maltase are two critical enzymes in the intestinal $\alpha$ glucosidase group and are considered key enzymes 
involved in the final step of carbohydrate digestion and glycoprotein biosynthesis. (Lee et al., 2012).

It is proven that acetic acid compounds slow stomach performance by inhibiting the activity of disaccharide enzymes in the small intestine and suppressing enteral carbohydrate absorption. (Mitrou et al., 2015). This is in line with Zubaidah \& Nuril (2015) statement that acetic acid can slow down the metabolic response in the body and increase insulin sensitivity to convert glucose into muscle sugar so that the increase in glucose levels in the blood can be controlled and reinforced. Johnston \& Buller (2005) opinion is that acetic acid reduces the glycemic response of foods with high glucose levels by inhibiting disaccharides in the epithelium of the small intestine. Acetic acid can inhibit the activity of disaccharide enzymes, namely sucrose, maltase, trehalase and lactase. (Ogawa et al., 2000).

Blood sugar levels are the amount of glucose in human blood circulation. Glucose is an essential carbohydrate absorbed into the bloodstream as glucose is formed through the hydrolysis of starches and disaccharides in food and is the primary metabolic fuel in humans. However, damage to pancreatic function leads to an increase in fasting blood sugar levels. High fasting blood sugar levels are affected by consuming high sugar foods (Murray et al., 2017; Rudi \& Kwureh, 2017). John E. Gerich, M.D. revealed that a healthy person in a fasting state would have a blood glucose level of 70 to $105 \mathrm{mg} / \mathrm{dL}$, and a person in a fasting state is considered diabetic if they have blood glucose levels above $126 \mathrm{mg} / \mathrm{dL}$ (Estela, 2019).

Diabetes mellitus is a chronic metabolic disease or disorder with multietiology characterised by high blood sugar levels (hyperglycemia), this disease can not be cured but can be controlled by regulating blood sugar levels (Putri et al., 2013). Poor diet is one of the causes of rising blood sugar levels in people with diabetes mellitus. Consuming carbohydrates that index high glycemic will increase the rate of absorption of blood sugar and trigger the secretion of the pancreatic hormone insulin, resulting in a spike in blood sugar levels in the body (Idris, Jafar, 2014).

Acetic acid can inhibit the performance of sucraseisomaltase enzymes, so blood sugar levels in the body can be controlled. Based on the results of the molecular docking visualisation, it can be seen that there is a good acetic acid binding pose to the enzyme sucrase-isomaltase even though the binding affinity is not too low, which is only -3.2 $\mathrm{kcal} / \mathrm{mol}$ and there is a binding site that is the interaction of hydrophobic and hydrogen bonding in the amino acid protein 3LPO tethered. This can be used as a proof of the trust of the indigenous people of Kampung Kuta, namely the treatment of palm vinegar as a control of blood sugar levels.

\section{Conclusion}

Ligands in the form of acetic acid compounds have been shown to inhibit the activity of disaccharide enzymes in the small intestine, so the epithelium of the small intestine will more slowly absorb that food juices. This will slow down the metabolic response to increasing the sensitivity of insulin in converting glucose into sugar. Testing the results of reverse docking is $-3.2 \mathrm{kcal} / \mathrm{mol}$, while the results of twodimensional molecular docking visualise the binding site, namely hydrophobic interactions in amino acids Trp327(A), Asp355(A), Ile392(A), Trp470(A), Phe604(A), His629(A), Trp586(A) and hydrogen bonds in amino acids Asp472(A).

\section{Declaration statement}

The authors reported no potential conflict of interest.

\section{References}

Andi, M. I., Nurhaedar J., R. I. (2014). Pola Makan Dengan Kadar Gula Darah Pasien DM Tipe 2. Jurnal MKMI, 211-218.

Baharuddin, Syahidah, \& Yatni, N. (2009). Penentuan Mutu Cuka Nira Aren (Arenga pinnata) Berdasarkan SNI 01-4371$1996 . \quad$ Perennial, 31 https://doi.org/10.24259/perennial.v5i1.187

Beheshti, Z., Chan, Y. H., Nia, H. S., Hajihosseini, F., Nazari, R., Shaabani, M., \& Omran, M. T. S. (2012). Influence of Apple Cider Vinegar on Blood Lipids. Life Science Journal, 9(4), $2431-2440$

Casem, M. L. (2016). Case Studies in Cell Biology. https://doi.org/10.1016/B978-0-12-801394-6/00009-9

Estela, C. (2019). Blood Glucose Levels. Blood Glucose Levels, 3(2). https://doi.org/10.5772/intechopen.73823

Ferdinal, F. (2005). Enzim : Peranan Biologik, Transformasi Ganas dan Transduksi Sinyal. 11.

Hairunnisa, H. (2019). Sulitnya Menemukan Obat Baru di Indonesia. Majalah Farmasetika, 4(1), 16. https://doi.org/10.24198/farmasetika.v4i1.22517

Hardoyo, Tjahjono, A. E., Primarini, D., Hartono, \& Musa. (2017). Kondisi Optimum Fermentasi Asam Asetat Menggunakan Acetobacter Aceti B166. J. Sains MIPA, 13(1), 17-20.

Johnston, C. S., \& Buller, A. J. (2005). Vinegar and Peanut Products as Complementary Foods to Reduce Postprandial Glycemia Journal of the American Dietetic Association, 105(12), 19391942. https://doi.org/10.1016/j.jada.2005.07.012

Kemp, M. L. (2013). Encyclopedia of Systems Biology (W. Dubitzky, O. Wolkenhauer, K.-H. Cho, \& H. Yokota (eds.)). https://doi.org/10.1007/978-1-4419-9863-7_323

Kharkar, P. S., Warrier, S., \& Gaud, R. S. (2014). Reverse Docking: A Powerful Tool for Drug Repositioning and Drug Rescue. Future Medicinal Chemistry, 6(3), 333-342. https://doi.org/10.4155/fmc.13.207

Lee, B. H., Quezada-Calvillo, R., Nichols, B. L., Rose, D. R., \& Hamaker, B. R. (2012). Inhibition of Maltase-glucoamylase Activity to Hydrolyse $\alpha-1,4$ Linkages by the Presence of Undigested Sucrose. Journal of Pediatric Gastroenterology and Nutrition, 55(SUPPL.2), 45-47. https://doi.org/10.1097/01.mpg.0000421415.95751.f7

Mitrou, P., Petsiou, E., Papakonstantinou, E., Maratou, E., Lambadiari, V., Dimitriadis, P., Spanoudi, F., Raptis, S. A., \& Dimitriadis, G. (2015). Vinegar Consumption Increases Insulin-Stimulated Glucose Uptake by the Forearm Muscle 
in Humans with Type 2 Diabetes. Journal of Diabetes Research, 2015. https://doi.org/10.1155/2015/175204

Murray, R. K., Bender, D. A., Botham, K. M., Kennelly, P. J., Rodwell, V. W., \& Weil, P. A. (2017). Biokimia Harper (R. Soeharsono, F. Sandra, \& H. O. Ong (eds.); 29th ed.). McGraw-Hill Higher Education.

Ogawa, N., Satsu, H., Watanabe, H., Fukaya, M., Tsukamoto, Y., Miyamoto, Y., \& Shimizu, M. (2000). Acetic Acid Suppresses the Increase in Disaccharidase Activity that Occurs During Culture of Caco-2 Cells. Journal of Nutrition, 130(3), 507513. https://doi.org/10.1093/jn/130.3.507

Pangastuti, A., Amin, M., \& Indriwati, E. S. (2016). Mengungkap Potensi Senyawa Alami Melalui Teknik Reverse Docking. Prosiding Seminar Nasional II 2016, Kerjasama Prodi Pendidikan Biologi FKIP Dengan Pusat Studi Lingkungan Dan Kependudukan (PSLK) Universitas Muhammadiya Malang, 1, 1019-1028.

Park, K., \& Cho, A. E. (2017). Using Reverse Docking to Identify Potential Targets for Ginsenosides. Journal of Ginseng Research, 41(4), 534-539. https://doi.org/10.1016/j.jgr.2016.10.005

Putri, H., Yeni, F., \& Handayani, T. (2013). Hubungan Peran Keluarga Dengan Pengendalian Kadar Gula Darah Pada Pasien Diabetes Melitus di Wilayah Kerja Puskesmas Pauh Padang. NERS Jurnal Keperawatan, 9(2), 136. https://doi.org/10.25077/njk.9.2.136-142.2013

Rudi, A., \& Kwureh, H. N. (2017). Faktor Risiko yang Mempengaruhi Kadar Gula Darah Puasa Pada Pengguna Layanan Laboratorium. Jurnal Ilmiah Ilmu Kesehatan: Wawasan Kesehatan, 3(2). https://doi.org/10.31227/osf.io/d3kes

Ruiz-Moreno, A. J., Domling, A., \& Velasco-Velazquez, M. A. (2020). Cancer Cell Signaling. In M. Robles-Flores (Ed.), Cancer Cell Signaling (Third). Humana Press. https://doi.org/10.1385/1592593569

Sugiyono. (2016). Metode Penelitian Kuantitatif, Kualitatif, dan $R \& D$ (23rd ed.). ALFABETA

Susanti, R., \& Febriana, F. (2017). Teknologi Enzim. CV ANDI OFFSET.

Toonen, R. J., Nakayama, T., Ogawa, T., Rossiter, A., \& Delbeek, J. C. (2012). Growth of cultured giant clams (Tridacna spp.) in low $\mathrm{pH}$, high-nutrient seawater: Species-specific effects of substrate and supplemental feeding under acidification. Journal of the Marine Biological Association of the United Kingdom, 92(4), 731-740. https://doi.org/10.1017/S0025315411000762

Wahyuni, S. (2017). Biokimia Enzim dan Karbohidrat. Unimal Press.

Zheng, R., Chen, T. sheng, \& Lu, T. (2011). A Comparative Reverse Docking Strategy to Identify Potential Antineoplastic Targets of Tea Functional Components and Binding Mode. International Journal of Molecular Sciences, 12(8), 52005212. https://doi.org/10.3390/ijms12085200

Zubaidah, E., \& Nuril F, I. (2015). Efek Cuka Apel dan Cuka Salak terhadap Penurunan Glukosa Darah dan Histopatologi Pankreas Tikus Wistar. Kedokteran Brawijaya, 28(4), 297301. 